\title{
Rhodopseudomonas faecalis sp. nov., a phototrophic bacterium isolated from an anaerobic reactor that digests chicken faeces
}

\footnotetext{
${ }^{1}$ Institute of Microbiology, Chinese Academy of Sciences, Beijing 100080, P. R. China

2 Department of Biology, Liaoning Normal University, Dalian, 116021, P. R. China
}

\author{
Demin Zhang, ${ }^{1,2}$ Huifang Yang, ${ }^{1}$ Zhiyong Huang, ${ }^{1}$ Wei Zhang ${ }^{1}$ \\ and Shuang-Jiang Liu ${ }^{1}$
}

\begin{abstract}
Author for correspondence: Shuang-Jiang Liu. Tel: +86 10 62527118. Fax: + 861062652317. e-mail: shuangjiang@hotmail.com
\end{abstract}

Five isolates of a previously undescribed species of purple non-sulfur phototrophic bacteria were characterized. They were Gram-negative, had mobile, budding vibrioid cells and contained lamellar intracytoplasmic membranes. Cultures produced red pigments in the light. Live cells of photosynthetic cultures exhibited absorption maxima at 382, 460-464, 494-496, 534-538, 596, 804-806 and 870-874 $\mathrm{nm}$, indicating the presence of bacteriochlorophyll a and carotenoids belonging to the spirilloxanthin series in cells. The new isolates grew anaerobically or microaerobically in the light, but not aerobically in the dark. Optimal growth occurred at $35-40{ }^{\circ} \mathrm{C}$ and at pH 6.5-8.5. Various organic compounds were used as photosynthetic electron donors and carbon sources. Sulfate was used as sulfur source for growth. Ubiquinone 10 was synthesized as the major quinone. A phylogenetic analysis based on 165 rRNA gene sequences revealed that strain $\mathrm{gc}^{\top}$, a representative of the new isolates, was closest to Rhodopseudomonas palustris, with a similarity of $97.5 \%$. DNA-DNA hybridization further distinguished strain $\mathrm{gc}^{\top}$ from Rhodopseudomonas palustris at the species level. Therefore, the name Rhodopseudomonas faecalis sp. nov. was proposed for the new isolates. The type strain is gc $^{\top}\left(=\right.$ AS1.2176 $\left.^{\top}=J C M 1^{11668}{ }^{\top}\right)$.

Keywords: purple non-sulfur phototroph, Rhodopseudomonas, 16S rRNA, taxonomy

\section{INTRODUCTION}

Purple non-sulfur phototrophs occur widely in environments. Most species of this bacterial group, like the species of the genus Rhodopseudomonas, are able to grow anaerobically in the light or aerobically in the dark with different carbon sources and electron donors. In Bergey's Manual of Systematic Bacteriology, the genus Rhodopseudomonas included seven species: Rhodopseudomonas palustris, Rhodopseudomonas viridis, Rhodopseudomonas sulfoviridis, Rhodopseudomonas acidophila, Rhodopseudomonas blastica, Rhodopseudomonas rutila and Rhodopseudomonas marina (Imhoff \& Trüper, 1989). Since then, the

Published online ahead of print on 19 April 2002 as DOI 10.1099/ ijs.0.02259-0.

The GenBank accession number for the $16 \mathrm{~S}$ rRNA gene sequence of strain $\mathrm{gc}^{\top}$ is AF123085. taxonomy of Rhodopseudomonas has been subject to significant changes on the basis of increasing molecular and chemotaxonomic information. These changes include the rejection of Rhodopseudomonas rutila from this genus (Hiraishi et al., 1992), the reclassification of Rhodopseudomonas rosea and Rhodopseudomonas marina as Rhodoplanes roseus and Rhodobium marinum (Hiraishi \& Ueda, 1994; Hiraishi et al., 1995), and the transfer of Rhodopseudomonas blastica to the genus Rhodobacter (Kawasaki et al., 1993). Rhodopseudomonas viridis and Rhodopseudomonas sulfoviridis were transferred to a new genus, Blastochloris (Hiraishi, 1997). Most recently, Rhodopseudomonas acidophila has been transferred to a newly established genus, Rhodoblastus (Imhoff, 2001).

In this paper, we describe the isolation, characterization and identification of a new phototrophic purple non-sulfur bacterium that was isolated from an anaerobic reactor digesting chicken faeces. Based on 
the phenotypic characteristics and molecular studies on the isolates, we classified the bacterium as a new species of the genus Rhodopseudomonas, for which the name Rhodopseudomonas faecalis is proposed.

\section{METHODS}

Bacterial strains, media, and cultivation. Out of five isolates obtained from the effluent of an anaerobic digester treating chicken manure, strain $\mathrm{gc}^{\mathrm{T}}$ was studied and characterized in detail. Rhodopseudomonas palustris ATCC 17001 ${ }^{\mathrm{T}}$ and ATCC 33872 were kindly provided by Professors J. F. Imhoff (Kiel, Germany) and T. Nakase (RIKEN, Japan), respectively.

ATM medium was modified from AT medium (Imhoff \& Trüper, 1992) by addition of $0 \cdot 1 \%$ sodium acetate and $0 \cdot 1 \%$ sodium succinate, and by deletion of sodium bicarbonate. ATYP medium was created by addition of $0.05 \%$ yeast extract and $0.03 \%$ peptone to ATM medium. ATM was used for physiological and chemical tests, and ATYP medium was used for growth and maintenance of the strains. Agar plates were prepared by addition of $1.5 \%$ agar to the medium. Soft agar was made by reducing the amount of agar to $0.7 \%$.

Routine cultivation was done anaerobically in screw-capped tubes or bottles filled with medium. Tubes or bottles were flushed with helium or nitrogen gas to remove oxygen. Incubation was conducted at $30-35^{\circ} \mathrm{C}$ under incandescent illumination of 1000-3000 lx.

Isolation. Samples were obtained from the effluent of an anaerobic digester treating chicken manure, located in the Northwest of China (Shan Xi province). The samples were diluted and inoculated into soft-agar tubes. The tubes were incubated anaerobically in the light. After 1 week cultivation, small red colonies appeared. Colonies were picked up and streaked on agar plates. The plates were placed in anaerobic jars, which were filled with argon and incubated under illumination. This was repeated three to five times to ensure the purity of the culture.

Microscopy. Morphology and ultrastructure of cells grown under illumination were observed by optical microscopy (Olympus BH-2) and by scanning (S-570; Hitachi) and transmission (H-600; Hitachi) electron microscopy.

Absorption spectrum. The absorption spectrum of intact cells grown under illumination was measured with spectrophotometers HP1050 (Hewlett Packard) for 300-820 nm, and Hitachi (model Hitachi) for 800-1400 nm.

Physiological characterization. Tests for photoassimilation of organic substrates were performed in screw-capped tubes containing ATM medium as described in Bergey's Manual (Imhoff \& Trüper, 1989).

DNA base composition and DNA-DNA hybridization. Genomic DNA was extracted and purified according to the method of Marmur (1961) except for the addition of protease $\mathrm{K}$ in the SDS-treating step. DNA base composition was determined by thermal denaturation (Marmur \& Doty, 1962). DNA-DNA hybridization was carried out as described by Tindall et al. (1984) with a minor modification: DNA fragments were labelled with $\alpha-{ }^{32} \mathrm{P}$ according to the instructions provided with the nick translation kit (Boehringer Mannheim).
Phylogenetic analysis. A 16S rDNA fragment was amplified and sequenced by using the MicroSeq 16 S rDNA Gene Kit (ABI Prism, 377 DNA Sequencer, Applied Biosystems). The 16S rRNA gene was amplified by using two primers: $27 \mathrm{f}\left(5^{\prime}\right.$ GAG AGT TTG ATC CTG GCT CAG-3') and 1541r (5'AAG GAG GTG ATC CAG CC-3'). Sequence alignment and analysis of the similarity of the $16 \mathrm{~S}$ rRNA gene were performed with the CLUSTAL W program (Thompson et al., 1994), and the SEQBOOT, DNADIST, NEIGHBOR-JOIN and CONSENSE programs of the software package PHYLIP version 3.5c (Felsenstein, 1993).

Quinone determination. Quinones were determined following Collins (1985) and Wu et al. (1989). The collected bacteria pellet was lyophilized, and treated with chloroform and methanol $(2: 1, \mathrm{v} / \mathrm{v})$. The quinones were separated on a 254 GF silica plate with n-hexane ethylether as the developing solvent. The number of isoprene units and the relative percentage of components of quinones were determined by HPLC (HP1074; Hewlett Packard) using the column Bondapak C18 $(3.9 \times 300 \mathrm{~mm}$, Waters). Rhodopseudomonas palustris ATCC $17001^{\mathrm{T}}$ and quinone 10 (standard sample) were used as the control.

Nucleotide sequence accession numbers. The GenBank accession number for the $16 \mathrm{~S}$ rRNA gene sequence of the test strain $\mathrm{gc}^{\mathrm{T}}$ is AF123085. The accession numbers of the reference strains are as follows: Rhodopseudomonas palustris ATCC $17001^{\mathrm{T}}$, D25312; Bradyrhizobium japonicum USDA 110, Z35330; 'Bradyrhizobium lupini', X87273; Nitrobacter hamburgensis $\mathrm{X} 14^{\mathrm{T}}$, L35502; Nitrobacter winogradskyi ATCC 25381 ${ }^{\mathrm{T}}$, L35506; Afipia felis ATCC 53690, M65248; Rhodoblastus acidophilus ATCC 25092, M34128; Blastochloris viridis ATCC 19567, D25314; Blastochloris sulfoviridis DSM 729, D86514; Rhodoplanes roseus DSM 5906 ${ }^{\mathrm{T}}$, D25313; Rhodopseudomonas rhenobacensis, AJ132402; Rhodoplanes elegans AS130, D25311; Rhodobacter azotoformans KA25, D70846; Rhodobacter sphaeroides ATCC 17023, X53855; Rhodobacter capsulatus ATCC 11166 ${ }^{\mathrm{T}}$, D16428; Rhodobium orientis JCM 9337, D30792; Rhodobium marinum DSM 2698 ${ }^{\mathrm{T}}$, D30790; Rhodospirillum rubrum ATCC 11170 ${ }^{\mathrm{T}}$, D30778; Phaeospirillum fulvum ATCC 15798, D14433; Rubrivivax gelatinosus ATCC $17011^{\mathrm{T}}, \mathrm{D} 16214$.

\section{RESULTS}

\section{Isolation}

The effluent from an anaerobic reactor digesting chicken faeces became reddish after illumination in a storage tank. We judged that the colour change resulted from the growth of phototrophic purple bacteria. Indeed, five isolates were obtained by direct cultivation of diluted samples of effluent. One isolate, strain $\mathrm{gc}^{\mathrm{T}}$, was studied further.

\section{Morphology and ultrastructure}

Strain $\mathrm{gc}^{\mathrm{T}}$ had Gram-negative vibrioid or peanutshaped cells. The cells were $0 \cdot 6-0 \cdot 8 \mu \mathrm{m}$ in width and $1 \cdot 2-2 \cdot 0 \mu \mathrm{m}$ in length (Fig. 1). The cells multiplied by budding and formed rosette-like clusters in old cultures. They were mobile by means of a single polar flagellum (Fig. 2). Electronic microscopy revealed that 


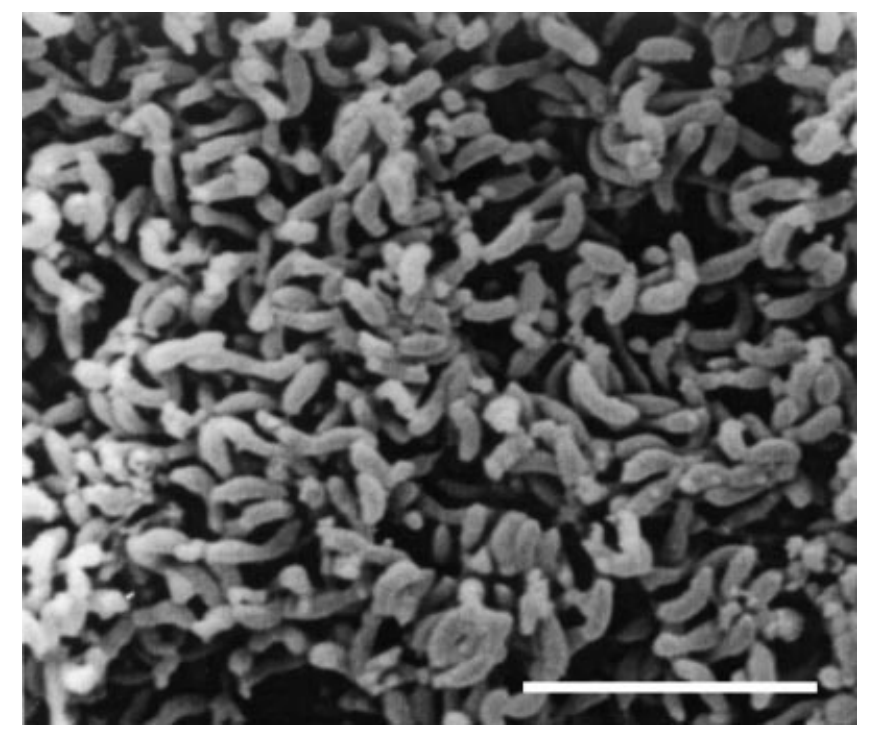

Fig. 1. Morphology of strain $\mathrm{gc}^{\top}$. Bar, $6 \mu \mathrm{m}$.

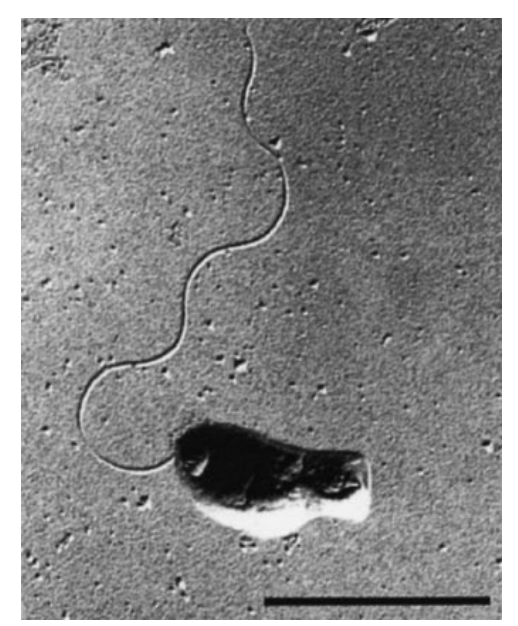

Fig. 2. Polar flagellum of strain $\mathrm{gc}^{\top}$. Bar, $6 \mu \mathrm{m}$.

phototrophically grown cells formed intracytoplasmic membranes of the lamellar type (Fig. 3), typical of the genus Rhodopseudomonas.

\section{Photopigments and quinones}

Round or lens-shaped colonies were formed in agar cultures or reddish suspension produced in liquid cultures when grown anaerobically under illumination. The absorbance maxima of phototrophically grown cells were 382, 460, 494, 534, 596, 806 and $870 \mathrm{~nm}$, indicating the presence of bacteriochlorophyll $a$ and carotenoids of the normal spirilloxanthin series. Examination of lipid extracts of lyophilized cells revealed that the predominant ubiquinone was ubiquinone 10. No menaquinone was detected.

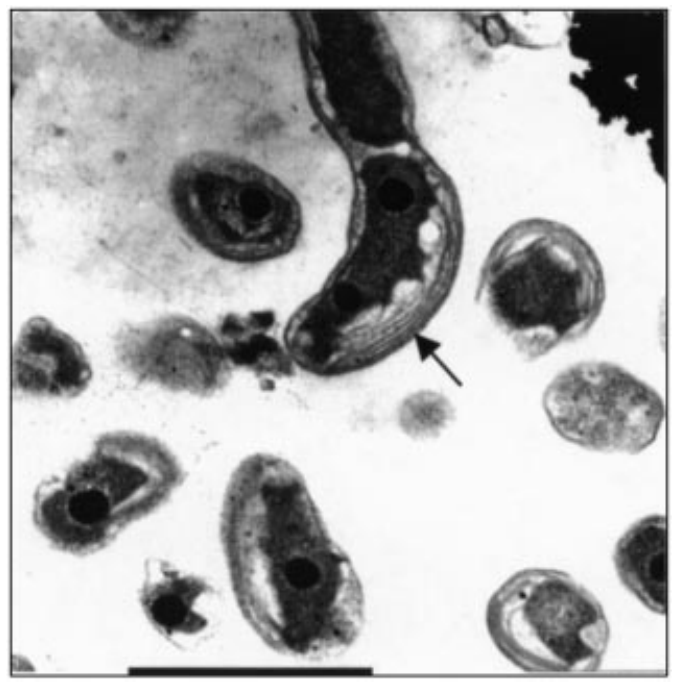

Fig. 3. Lamellar intracytoplasmic membranes of strain $\mathrm{gc}^{\top}$. Bar, $6 \mu \mathrm{m}$.

\section{Growth and physiological and biochemical characteristics}

The isolates were able to grow anaerobically in the light. They could not form colonies in darkness at full atmospheric oxygen tension, which is different from Rhodopseudomonas palustris. Strain $\mathrm{gc}^{\mathrm{T}}$ grew in the temperature range from 28 to $45^{\circ} \mathrm{C}$, with an optimum of $38^{\circ} \mathrm{C}$. When the five isolates were grown phototrophically in ATYP medium they exhibited a doubling time of $4-6 \mathrm{~h}$. They could not grow under anaerobic conditions in the dark, even when nitrate or DMSO was added as terminal electron acceptor. The $\mathrm{pH}$ range for growth was $6 \cdot 0-8 \cdot 5$, with an optimum of $7 \cdot 0$. No growth was found in the medium with $3 \%$ $\mathrm{NaCl}$. Thiamin was required for growth, but it could be replaced by $0.01 \%$ yeast extract.

Strain $\mathrm{gc}^{\mathrm{T}}$ was different from other species of the genus Rhodopseudomonas in carbon source assimilation. It showed a strong tendency for photoorganotrophy with simple organic compounds as electron donors and carbon sources (Table 1). Acetate, pyruvate, lactate, malate, succinate and butyrate supported good growth. Fumarate and propionate supported moderate growth. No growth was found with benzoate, citrate, formate, gluconate, tartrate, rhamnose, sorbitol, ethanol, methanol, mannitol, aspartate or glutamate. Strain $\mathrm{gc}^{\mathrm{T}}$ grew photoautotrophically with hydrogen and sodium bicarbonate. Sulfide and thiosulfate were not utilized as the electron donor. Ammonium salts and glutamate were used as nitrogen sources. Sulfate was used as sulfur source for growth.

\section{$\mathbf{G}+\mathbf{C} \mathbf{m o l} \%$ and DNA-DNA hybridization}

The $\mathrm{G}+\mathrm{C}$ content of the genomic DNA for strain $\mathrm{gc}^{\mathrm{T}}$ was $63.6 \mathrm{~mol} \%$. Strain $\mathrm{gc}^{\mathrm{T}}$ showed low levels of 
Table 1. Differential characteristics of strain $\mathrm{gc}^{\top}$, Rhodopseudomonas palustris and Rhodopseudomonas rhenobacensis

+ , Good growth; -, no growth; \pm , some strains only; b, biotin; t, thiamin dichloride; p-ABA, $p$-aminobenzonic acid; ND, not done. Data for Rhodopseudomonas palustris and

Rhodopseudomonas rhenobacensis were obtained from Imhoff \& Trüper (1989) and Hougardy et al. (2000).

\begin{tabular}{|c|c|c|c|}
\hline Characteristic & Strain $g^{T}$ & $\begin{array}{l}\text { Rhodopseudomonas } \\
\text { palustris } \\
{\text { ATCC } 17001^{\mathrm{T}}}^{\text {AT }}\end{array}$ & $\begin{array}{c}\text { Rhodopseudomonas } \\
\text { rhenobacensis AJ132402 }\end{array}$ \\
\hline Aerobic growth in dark & - & + & + \\
\hline Optimum pH & $7 \cdot 0$ & 6.9 & $5 \cdot 5$ \\
\hline Cell diameter $(\mu \mathrm{m})$ & $0 \cdot 5-0 \cdot 8$ & $0 \cdot 6-0 \cdot 9$ & $0 \cdot 4-0 \cdot 7$ \\
\hline Cell shape & $\begin{array}{l}\text { Vibrioid or } \\
\text { peanut shape }\end{array}$ & Rod & Rod \\
\hline Growth factor & $\mathrm{t}$ & p-ABA, b (some) & $\mathrm{p}-\mathrm{ABA}$ \\
\hline Nitrate-reduction & - & - & + \\
\hline \multicolumn{4}{|l|}{ Utilization of: } \\
\hline Aspartate & - & $+^{*}$ & $\mathrm{ND}$ \\
\hline Benzoate & - & + & - \\
\hline Ethanol & - & + & + \\
\hline Formate & - & - & + \\
\hline Fructose & \pm & \pm & - \\
\hline Gluconate & - & $+*$ & + \\
\hline Glucose & \pm & \pm & - \\
\hline Glutamate & - & -* & - \\
\hline Propionate & + & + & - \\
\hline Tartrate & - & - & + \\
\hline Xylose & - & + & $\mathrm{ND}$ \\
\hline
\end{tabular}

* Data are modified according to our results.

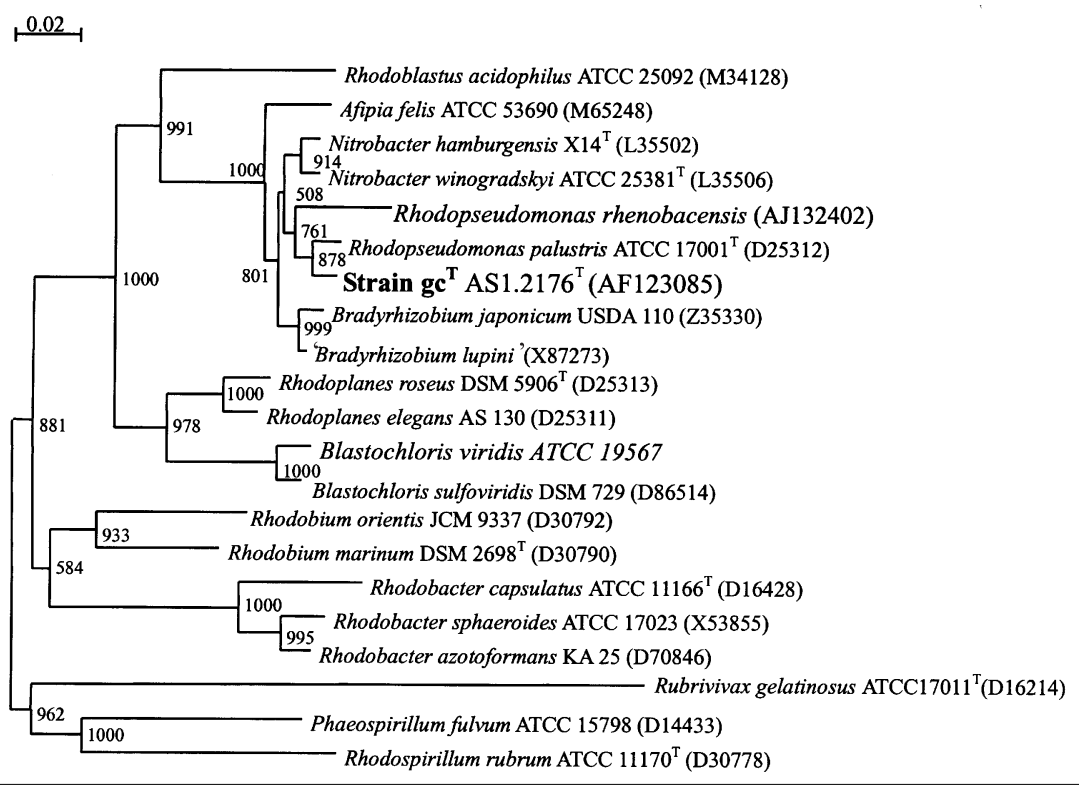

Fig. 4. Distance matrix tree showing phylogenetic relationships between the new isolate and related organisms. Bootstrap confidence values obtained from 1000 bootstrap replications are given at the branch points.
DNA-DNA hybridization $(17 \cdot 7 \%)$ to Rhodopseudomonas palustris ATCC $17001^{\mathrm{T}}$. The low level of genomic DNA relatedness supported the establishment of a new species of the genus Rhodopseudomonas.

\section{Phylogenetic relationships}

The 1444 bp representing more than $95 \%$ of the entire $16 \mathrm{~S} \mathrm{rRNA}$ gene were amplified from strain $\mathrm{gc}^{\mathrm{T}}$ and the 
sequence was determined. It had four degenerate bases at positions 258, 268, 379 and 384 (corresponding to Escherichia coli 16S rRNA numbering). A similarity search was done in the Ribosomal Database Project (RDP) (Maidak et al., 2001). The results showed that the sequence of strain $\mathrm{gc}^{\mathrm{T}}$ is closest to Rhodopseudomonas palustris ATCC $17001^{\mathrm{T}}$.

The 16S rDNA sequence of strain $\mathrm{gc}^{\mathrm{T}}$ was compared with a dataset consisting of 20 16S rRNA genes available from the RDP, including 15 of purple nonsulfur bacteria and 5 of closely related nonphototrophs of the $\alpha$-subclass of the Proteobacteria. Strain $\mathrm{gc}^{\mathrm{T}}$ was closest to Rhodopseudomonas palustris (97.5\%) and Rhodopseudomonas rhenobacensis (97\%). It also showed high similarities to five chemotrophic bacteria species ( $>97 \%$ similarity to Bradyrhizobium japonicum, 'Bradyrhizobium lupini', Nitrobacter hamburgensis, Nitrobacter winogradskyi and Afipia felis), as the other Rhodopseudomonas species did. A phylogenetic tree was constructed on the basis of evolutionarily corrected distances matrix (Fig. 4). Rubrivivax gelatinosus, which is in the $\beta$-subclass of the Proteobacteria, was used as outgroup. Strain $\mathrm{gc}^{\mathrm{T}}$ formed a close cluster with two species of Rhodopseudomonas (Rhodopseudomonas palustris and Rhodopseudomonas rhenobacensis) and five species of chemotrophic bacteria.

\section{DISCUSSION}

Strain $\mathrm{gc}^{\mathrm{T}}$ met the characteristic requirements of the genus Rhodopseudomonas: anaerobic photoheterotrophs, multiplying by budding, and forming the lamellar type of intracytoplasmic membrane. Cells contained bacteriochlorophyll $a$. Among the four species of Rhodopseudomonas, strain $\mathrm{gc}^{\mathrm{T}}$ most closely resembled Rhodopseudomonas palustris and Rhodopseudomonas rhenobacensis. However, substantial physiological differences existed between strain $\mathrm{gc}^{\mathrm{T}}$ and the above two species (Table 1). Strain $\mathrm{gc}^{\mathrm{T}}$ did not grow aerobically in dark, whereas both Rhodopseudomonas palustris and Rhodopseudomonas rhenobacensis did. Strain $\mathrm{gc}^{\mathrm{T}}$ required thiamin as a growth factor, whereas both Rhodopseudomonas palustris and Rhodopseudomonas rhenobacensis required aminobenzoic acid as a growth factor. Strain $\mathrm{gc}^{\mathrm{T}}$ did not utilize ethanol or gluconate as carbon sources whereas Rhodopseudomonas palustris and Rhodopseudomonas rhenobacensis did. More differences can be found in Table 1. Therefore, we classified strain $\mathrm{gc}^{\mathrm{T}}$ as a new species of the genus Rhodopseudomonas, and the name Rhodopseudomonas faecalis is proposed.

Phylogenetic analysis and DNA-DNA hybridization further supported strain $\mathrm{gc}^{\mathrm{T}}$ to be a new species of the genus Rhodopseudomonas. DNA-DNA hybridization results showed that strain $\mathrm{gc}^{\mathrm{T}}$ was clearly different from Rhodopseudomonas palustris at the species level (only $17.7 \%$ ), supporting the phenotypic differences. Molecular phylogenetic analysis based on $16 \mathrm{~S}$ rRNA gene sequences also indicated that strain $\mathrm{gc}^{\mathrm{T}}$ was different enough to be separated from other species of the genus Rhodopseudomonas (Fig. 4).

We propose a new name for strain $\mathrm{gc}^{\mathrm{T}}$ : Rhodopseudomonas faecalis.

\section{Description of Rhodopseudomonas faecalis sp. nov.}

Rhodopseudomonas faecalis (fae.ca'lis. L. adj. faecalis pertaining to faeces, as the organism was found in chicken faeces).

Cells are vibrioid or peanut-like, $0 \cdot 6-0 \cdot 8 \mu \mathrm{m}$ wide and $1 \cdot 0-2 \cdot 0 \mu \mathrm{m}$ long. Motile by means of polar flagella. Cells multiply by budding and asymmetric cell division. The daughter cell and mother cell resemble an ' $S$ '-form before separating from each other. Rosettelike clusters can be seen in old cultures. Gram-negative, $\alpha$-proteobacterium. Phototrophically grown cells contain intracytoplasmic membranes of the lamellar type. The absorption maxima of living cells are 382, 460464, 494-496, 534-538, 596, 804-806 and 870-874 nm. Thiamin is required as a growth factor and $0.05 \%$ yeast extract stimulates growth. Anaerobic phototroph. No growth under aerobic conditions. Ammonium salts are used as nitrogen sources. Sulfate is assimilated. Nitrate or DMSO cannot be used as a terminal electron acceptor. The $\mathrm{G}+\mathrm{C}$ content of the DNA is $63.6 \mathrm{~mol} \%$. Isolated from chicken faeces. The type strain is strain $\mathrm{gc}^{\mathrm{T}}$, which has been deposited in the Chinese Collection of Microorganisms, Beijing $\left(\mathrm{AS} 1.2176^{\mathrm{T}}\right.$ ), and in the Japan Collection of Microorganisms, RIKEN, Wako (JCM 11668 ${ }^{\mathrm{T}}$ ).

\section{ACKNOWLEDGEMENTS}

This work was supported by grants from the Chinese Academy of Sciences (BRJH-2000). We thank Dr Yi Xu for suggestions on DNA-DNA hybridization and phylogenetic analysis. We also appreciate Dr Kequan Pei for his help in phylogenetic tree construction. Gifts of Rhodopseudomonas palustris ATCC $17001^{\mathrm{T}}$ and ATCC 33872 by Professors J. F. Imhoff (Kiel, Germany) and T. Nakase (RIKEN, Japan) are highly appreciated.

\section{REFERENCES}

Collins, M. D. (1985). Isoprenoid quinone analyses in classification and identification. In Chemical Methods in Bacterial Systematics, pp. 267-287. Edited by M. Goodfellow \& D. E. Minnikin. Orlando: Academic Press

Felsenstein, J. (1993). PHYLIP (phylogeny inference package), version 3.5c. Department of Genetics, University of Washington, Seattle, USA.

Hiraishi, A. (1997). Transfer of the bacteriochlorophyll $b$-containing phototrophic bacteria Rhodopseudomonas viridis and Rhodopseudomonas sulfoviridis to the genus Blastochloris gen. nov. Int J Syst Bacteriol 47, 217-219.

Hiraishi, A. \& Ueda, Y. (1994). Rhodoplanes gen. nov., a new genus of phototrophic bacteria including Rhodopseudomonas rosea as Rhodoplanes roseus comb. nov. and Rhodoplanes elegans sp. nov. Int J Syst Bacteriol 44, 665-673.

Hiraishi, A., Santos, S. T., Sugiyama, J. \& Komagata, K. (1992). Rhodopseudomonas rutila is a later subjective synonym of Rhodopseudomonas palustris. Int J Syst Bacteriol 42, 186-188. 
Hiraishi, A., Urata, K. \& Satoh, T. (1995). A new genus of marine budding phototrophic bacteria, Rhodobium gen. nov., which includes Rhodobium orientis sp. nov. and Rhodobium marinum comb. nov. Int $J$ Syst Bacteriol 45, 226-234.

Hougardy, A., Tindall, B. J. \& Klemme, J.-H. (2000). Rhodopseudomonas rhenobacensis $\mathrm{sp}$. nov., a new nitrate-reducing purple non-sulfur bacterium. Int J Syst Evol Microbiol 50, 985-992.

Imhoff, J. F. (2001). Transfer of Rhodopseudomonas acidophila to the new genus Rhodoblastus as Rhodoblastus acidophilus gen. nov., comb. nov. Int J Syst Evol Microbiol 51, 1863-1866.

Imhoff, J. F. \& Trüper, H. G. (1989). Purple nonsulfur bacteria. In Bergey's Manual of Systematic Bacteriology, vol. 3, pp. 1658-1682. Edited by J. T. Staley, M. P. Bryant, N. Pfennig \& J. G. Holt. Baltimore: Williams \& Wilkins.

Imhoff, J. F. \& Trüper, H. G. (1992). The genus Rhodospirillum and related genera. In The Prokaryotes, 2nd edn, vol. 1, pp. 2141-2155. Edited by A. Balows, H. G. Trüper, M. Dworkin, W. Harder \& K. H. Schleifer. Heidelberg: Springer.

Kawasaki, H., Hoshino, Y., Hirata, A. \& Yamasato, K. (1993). Is intracytoplasmic membrane structure a generic criterion? It does not coincide with phylogenetic interrelationships among phototrophic purple nonsulfur bacteria. Arch Microbiol 160, 358-362.

Maidak, B. L., Cole, J. R., Lilburn, T. G. \& 7 other authors (2001). The RDP-II (Ribosomal Database Project). Nucleic Acids Res 29, 173-174.

Marmur, J. (1961). A procedure for the isolation of deoxyribonucleic acid from microorganisms. J Mol Biol 3, 208-218.

Marmur, J. \& Doty, P. (1962). Determination of the base composition of deoxyribonucleic acid from thermal denaturation temperature. $J \mathrm{Mol}$ Biol 5, 109-118.

Thompson, J. D., Higgins, D. G. \& Gibson, T. J. (1994). CLUSTAL W: improving the sensitivity of progressive multiple sequence alignment through sequence weighting, position-specific gap penalties and weight matrix choice. Nucleic Acids Res 22, 4673-4680.

Tindall, B. J., Ross, H. N. M. \& Grant, W. D. (1984). Natronobacterium gen. nov. and Natronococcus gen. nov., two new genera of haloalkaliphilic archaebacteria. Syst Appl Microbiol 5, 41-57.

Wu, C., Lu, X., Qin, M. \& Ruan, J. (1989). Analysis of quinone in cells of microorganisms by HPLC method. Chin Microbiol 16, 176-178. 